\title{
Preparation of Edible Film Based on Egg White Protein Powder to Prolong Shelf Life of Chicken Patties
}

Aboul-Anean, H. E. ${ }^{1}$; Samaa M. EL-Sayed ${ }^{2}$ and Eman Abdel Bakhy ${ }^{1}$

${ }^{1}$ Food Engineering and Packaging Dept. Food Tech. Res. Institute, Agric. Res. Center, Giza, Egypt

${ }^{2}$ Food Science and Technology Dept. Faculty of Home Economics , AL-Azhar University, Tanta, Egypt

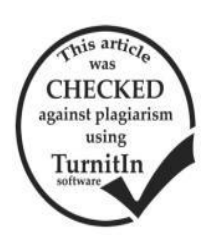

\begin{abstract}
The aim of this study was to produce an edible film from egg white protein powder and the theological, mechanical properties,permeability and scanning electron microscopy (SEM) of the prepared films were determined. The thickness, tensile strength , elongatio ,\% solubility of produced by edible film with rosemary essential oil was the highest, followed by that of egg protein powderbased film with tripolyphosphate (TPP). Therefore, the addition of rosemary essential oil or (TPP) to egg white protein powder films have the potential to provide a safe edible films decreased microbial growth and consequently prolonged the shelf life of chicken patties, As well as improved the chemical changes and sensory properties of the chicken patties. The substances used in this experiment were, film with glycerin (A), film with sorbitol (B), film with rosemary essential oil (C) and film with tripolyphosphate (D) compared with $(\mathrm{CL})$ on quality attributes and prolong shelf- life of chicken patties during storage. All products were stored at $\left(4 \pm 1^{\circ} \mathrm{C}\right)$ for 30 days and the quality parameters such as total volatile nitrogen (TVB-N), thiobarbituric acid (TBA), WHC, plasticity, pH, weight loss, moisture content, total bacteria count, psychrophilic bacteria (Psy) and molds and yeasts (M\&Y) were determined. The results observed that treatment $(\mathrm{C})$ was the best treatment in terms of reduction of microbial load followed by treatment (D) followed by treatment (B) until 30 days of storage as compared to control (CL). The levels of decrease in chemical and microbial load in the samples from both of the edible films were related good quality chicken patties. As well as on the same physic -chemical tests and sensory. It is clear that the edible coating and films of the aromatic essential oils and the (TPP) have kept the Quality of chicken patties up to 30 days of storage.
\end{abstract}

Keywords: chicken patties, egg white protein powder, edible films, theological, mechanical properties, Permeability, microbial, physico-chemical and edible coating.

Corresponding Author: Hosam El din Aboul-Anean, Food Engineering and Packaging Dept.Food Tech. Res. Institute, Agric. Res Center, Giza, Egypt E-mail: hosam.ftri@yahoo.com and Samaa Mahmoud El-Sayed, Food Science and Technology Department, Faculty of Home Economic, Al-Azhar University, Tanta, Egypt. Email: samaa.mahmoud@azhar.edu.eg , dr.samaamahmoud@yahoo.com

\section{INTRODUCTION}

Chicken egg albumin white is a perfect source of proteins, lipids, minerals and vitamins. Proteins of egg are distributed between the egg white and egg yolk. Egg white consists of water $(88 \%)$, protein $(11 \%)$ and trace amounts (1\%) of carbohydrates, lipids and ash (Kovacs-Nolan et al., 2005). These proteins are recognized by their functional properties such as nutritional health (Ko and Ahn, 2008), and antimicrobial effects. The antimicrobial and antiviral effects of egg white proteins are associated with its protein content, in particular lysozyme, which is registered for use as a preservative in some foods by WHO and is referred to as a bacteriolytic protein (Kovacs-Nolan et al., 2005). Egg white protein can be hydrolyzed by various enzymes (pepsin, trypsin and $\alpha$ - chymotrypsin) in different conditions (Abeyrathne et al., 2013). Egg white has been studied for its film properties (Catherine Nettles Cutter, 2006). Protective egg albumen coatings have been applied to raisins and cast albumen films with added lysozyme to inhibit bacterial growth showed potential as active packaging (Nelson Caro et al., 2016). Covalent disulfide (S-S) bonds are considered important for film formation with proteins containing cysteine and/or cysteine amino acids such as egg protein, which has a substantial cysteine content $(2.17 \mathrm{~g} / 100 \mathrm{~g}$ dry wtight) (Mine, 1995). Since S-S bonds involved in network formation in cast egg white films (MINE, 1992, 1996). Edible films are also used as a carrier matrix for antimicrobial and antioxidant agents (Bourtoom, 2008). Essential oils are frequently used to control the growth of pathogenic bacteria and prevent degradation in foods (Burt, 2004; Zivanovic et al., 2005). Inedible film systems, an antimicrobial agent slowly passes from the film layer to the food and thus a high concentration of antimicrobial agent remains in the film and at the surface of the food, providing a longer effect against microorganisms (Coma et al., 2002). Coatings and films made from a number commodities have been developed that offer a variety of advantages to fresh and further processed meats and poultry such as edibility, bio compatibility, aesthetic appearance, and barrier properties. In this respect it was found that Aristippos Gennadios (1997) As an application of active packaging, edible films carrying antioxidants and / or antimicrobials can be used for direct treatment of meat surfaces, thereby delaying meat rancidity and discoloration, and reducing microbial loads. Antimicrobial edible films are an innovative approach within the frame of active packaging concept because of their favorable interaction with the food by increasing shelf life and improving safety and even organoleptic properties KukHwan Seol et al., (2009). Therefor the purpose of this work was to produce an edible film from egg white protein powder and studying its effects on quality properties and shelf- life of chicken patties during storage

\section{MATERIALS AND METHODS}

\section{Materials:}

Chicken breast meat $(5 \mathrm{~kg})$ was purchased from the wholesale chicken market Giza, Egypt. Chicken breast meat was transferred to the laboratory in an ice box within $30 \mathrm{~min}$, then subjected to the technological processes: Egg albumin white protein powder (EWPP) was obtained from the allied chemical group (A.C.G). NaOH and Glycerin (P05650, ElGomhouria Company. Rosemary essential oil was obtained from Across Organics(Belgium) . Sorbitol and Tripolyphosphate (TPP) obtained from Un/1823 chemical comp., UK. 


\section{Methods:}

Preparation of chicken patties :

Chicken breast meat was cut off, washed gently with tap water and shredded by a kitchen grinder using a $2 \mathrm{~mm}$ hole plate. Chicken patties formulated to contain $90 \%$ Chicken meat , 5\% Starch , 2\% salt , 1.5\% Onion powder, $0.5 \%$ Garlic powder and $1 \%$ Spice mix (45\% Black pepper, 45\% Cumin , 7.5\%Coriander, $2.5 \%$ Red pepper)

Preparation of edible film solution from egg white protein powder .

Four edible films were prepared from egg protein powder (EWPP) by suspension solution consisting of 5\% $\mathrm{w} / \mathrm{v}$ (EWPP) in $100 \mathrm{ml}$ of distilled water according to Nazan KAVAS and Gökhan KAVAS (2016). The edible films were formulated to contain $3 \% \mathrm{w} / \mathrm{v}$ sorbitol, $3 \% \mathrm{v} / \mathrm{v}$ glycerin, $1 \% \quad \mathrm{v} / \mathrm{v}$ rosemary essential oil or $1 \%$ tripolyphosphate. Edible film mixtures were manually homogenized and their $\mathrm{pH}$ values were adjusted to 8 and kept in a water bath at $45 \pm 2{ }^{\circ} \mathrm{C}$ for $30 \mathrm{~min}$, then an edible film solution was filtered and poured on Teflon which used as casting surface, after drying films were seprated from plates. Table (1) shows the formuals of edible films:

Table 1. Edible film formulas

\begin{tabular}{|c|c|c|c|c|c|}
\hline \multirow[b]{2}{*}{$\begin{array}{l}\text { Film } \\
\text { code }\end{array}$} & \multirow[b]{2}{*}{ EWPP } & \multicolumn{4}{|c|}{ Film components \% } \\
\hline & & Sorbitol & Glycerin & $\begin{array}{l}\text { Rosemary } \\
\text { essential oil }\end{array}$ & TPP \\
\hline$\overline{\mathrm{A}}$ & 5 & 3 & - & - & - \\
\hline B & 5 & - & 3 & - & - \\
\hline $\mathrm{C}$ & 5 & - & - & 1 & - \\
\hline$\underline{\mathrm{D}}$ & 5 & - & - & - & 1 \\
\hline
\end{tabular}

The prepared chicken patties divided into 5 batches, one uncoated (control), the remainder four batches were immersed in the different film forming solution for $5 \mathrm{~min}$., then removed, let to drain, kept in the refrigerator at 4 OC then analyzed every 5 days to evaluated the effect of edible films on the quality characteristics of chicken patties.

Physical and mechanical and rheological properties of edible film of egg white protein powder:

1- Rheological measurements: Rheological parameters (shear rate and shear stress) of the selected_best solution of films and coatings were measured using a Brookfield Engineering labs DV- III Rheometer at $30^{\circ} \mathrm{C}$. The samples were placed in a small sample adapter and a constant temperature water bath was used to maintain the desired temperature. The Viscometer was operated between 10 and 60 RPM . The sc4-25 spindle was selected for the measurement.

2- Film thickness: The thickness of the prepared edible film was measured on a micrometer (Mitutoyo digimatic indicator corporation, model: Polk -1012 E, Japan). Film strips were placed between the micrometer jaws and gap was slowly reduced until the first contact was noted. ( Tien et al ., 2000).

3- Percentage of solubility : The films specimens were first dried in a desiccator containing dry calcium chlorides . A dry film sample of $500 \mathrm{mg}$ was immersed in beakers containing $50 \mathrm{ml}$ of distilled water at room temperature during 24 hours with periodical gentle shaker incubator. Films were removed from the water and placed back in the desiccator until constant weight. Loss of weight in water was reported as a percentage of weight loss in water on the dry film basis according to Munoz et al. (2004) .

$$
\% \text { weight loss }=\frac{\text { Initial dry weight }- \text { final dry weight } \times 100}{\text { Initial dry weight }}
$$

4- Film of mechanical properties : The tensile properties (Tensile strength, elongation) were measured by a texture analyzer CT3. The films were cut into strips $3 \times 5 \mathrm{~cm}$. according to Hernandez (2004).

5- Determination of Water vapor permeability (WVP): The water vapor transmission rate $\left[\mathrm{g} /\left(\mathrm{s}_{\mathrm{m}} \mathrm{m}^{2}\right)\right]$ and (WVP) through films was determined gravimetrically using the ASTM Method E96-95. A circular test cup was used to determine the WVP of the film. The film was first cut into a circular shape that was larger than the inner diameter of the cup, the cup was filled with $50 \%$ distilled water and the film was sealed at the top using Paraffin oil, then the cups were placed in a desiccator containing calcium chloride. The weights of the cups were recorded every hour during 10 hours and two specimens of each film were tested. Linear regression was used to estimate the slope of this line in $\mathrm{g} / \mathrm{h}$. The (WVTR) and water vapor permeability was determined using the following equation:

$$
\mathrm{WVPR}=\frac{\Delta m}{\Delta t A} \quad \mathrm{WVP}==\frac{\text { WVTR. } \mathrm{L}}{/ \Delta R H}
$$

Where, $\Delta m / \Delta t$ is the moisture gain, weight per time $(\mathrm{g} / \mathrm{s}), \mathrm{A}$ is the surface area of the film $\mathrm{m} 2, \mathrm{~L}$ is the film thickness $(\mathrm{mm})$ and $\Delta R H$ is the difference in relative humidity.

\section{6- Measurement of gas Permeability:}

Gas $(\mathrm{O} 2$ and $\mathrm{CO} 2)$ permeability at $30^{\circ} \mathrm{C}$ was measured in a designed stainless cell using a gas testing instrument, model Witt Oxybaby headspace gas analyser $(\mathrm{O} 2 / \mathrm{CO} 2)$ following the method described by García et al. (2000). The gas permeability (P) was calculated according to the following equation:

$$
\mathbf{P}=\frac{\mathbf{Q} \cdot \mathbf{x}}{\text { A.t. } \Delta \mathbf{P}}
$$

Where, $\mathrm{P}$ is the permeability of gas, $\left(\mathrm{m}^{3} / \mathrm{m}\right.$. Day . Mm Hg $), Q$ is the quantity of the gas diffused $m 3, X$ is the thickness of the film , $A$ area of the film, $m 2, t$ is the time,day and $\Delta p$ is the pressure difference across the film.

\section{7- Scanning electron microscopy by :}

The scanning Electron Microscope (SEM) photographs were carried out for 2 samples. Using SEM Model Philips XL 30 attached to EDX Unit, with accelerating voltage 5 K.V. XL 30, Philips, Netherlands, Made in 5600MD Eindhoven-Holanda . (Sotelo-Boy et al., 2015).

Physico-chemical, sensory evaluation and microbial analysis of chicken patties:-

1- Moisture contents and weight loss : were determined using the methods of the A O A C (2000).

2- Determination of Total Volatile Basic Nitrogen (TVB-N) : (TVB-N) value was estimated by the semimicro distillation Procedure(AMC, 1979 and Kirk and Sawyer, 1991). The bases are steam distilled into Standard acid and back-titration with standard alkali.

3- Determination of Thiobarbituric Acid (TBA): (TBA) value of chicken patties samples was determined colorimetrically by using the method published by (Kirk and Sawyer 1991). 
4- The pH value determination: The $\mathrm{pH}$ value for chicken patties was determined by using a calibrated pH meter (Beckman model 3550, USA) according to the procedure of Schoeni et al. (1991).

5- Water holding capacity (WHC): Water holding capacity (WHC) was determined by the filter press method described by Soloviev (1966).

6- Microbial examination: Total bacterial count was determined according to Marshall, (1992) in duplicates by using plate count agar medium. The plates were incubated at $37^{\circ} \mathrm{C}$ for 48 hours. Where Pychrophilic bacterial incubated at $4^{\circ} \mathrm{C}$ for 5 days were estimated using plate count agar medium. The plates were Molds and yeast counts were determined using the methods described by the American Public Health Association (APHA, 1976) by using malt extract agar medium The plates were incubated at $25^{\circ} \mathrm{C}$ for 5 days. Detection of Salmonella according to the method described by FAO (1979), where detection of Escherichia coli (Tryptone Bile X-glucuronide (TBX) Medium Oxoid CM945) was carried out according to FDA (2000; ISO 2001).

7- Sensory evaluation: Chicken patties were sensory evaluated for appearance, flavor,texture and overall acceptability. The panel consisted of ten members and scores were obtained as described by DLG (1973). The rejection of samples was based on appearing of the putrid smell of samples.

8- Statistical Analysis: Data were subjected to the proper statistical analysis using the MSTAT statistical software. The mean values were compared using the LSD method at 5\% level version 17.0. The data were tabulated and statistically analyzed using factorial analyses according to the completely randomized design (Snedecor and Cochran 1989).

\section{RESULTS AND DISCUSSION}

\section{Rheological properties of edible films from egg white} protein powder:

The relation between shear rate and shear stress and viscosity of selected edible films and coating is shown in Table (2) and Figure, (1). The results show that samples exhibited non-Newtonian pseudoplastic behavior and fits the power low well into the following equation:

$$
\mathbf{\tau}=\mathbf{k} \boldsymbol{\gamma}^{\mathrm{n}} \rightarrow(1)
$$

Where : $\tau$ : shear stress,pa $\gamma$ : shear rate $1 /$ sec, $\mathrm{k}$ : consistency index, n: flow behavior index

The shear rate increased as shear stress, increased while the flow behavior since the results indicated that $n<1$ but we can approximate that it behaviors as pseudoplastic. On the other hand consistency index $(\mathrm{k})$ decreased and flow behavior index (n) increased for treatments B, C, D, except for treatment A, The best forming solution for the applications of naturally films and for coating of fruit and vegetables. Also, this may be due to consistency affected by changes in concentrate and interaction effect was performed with the average value of $(\mathrm{k})$ and $(\mathrm{n})$ for each treatment level and absolute correlated one of the parameters should be eliminated by expressing it as a function of another creating a one parameter model as reported by Hagenimana et al. (2007) and Sui sui Jiang (2016).

Table 2. Relation between (k) and (n) at egg protein powder on emulsion produced edible films

\begin{tabular}{|c|c|c|c|}
\hline Treatments & K & $\mathbf{n}$ & $\mathbf{R}^{2}$ \\
\hline $\bar{A}$ & 1.1196 & 0.142 & 0.8964 \\
\hline B & 0.8569 & 0.1596 & 0.8485 \\
\hline $\mathrm{C}$ & 0.7406 & 0.1794 & 0.9156 \\
\hline$\underline{\mathrm{D}}$ & 0.031 & 0.3895 & 0.9508 \\
\hline
\end{tabular}

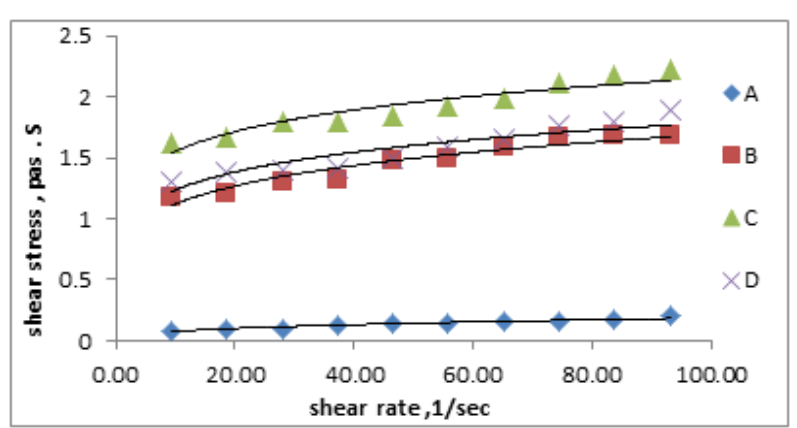

Fig. 1. Shear rate and Shear Stress at egg protein powder on emulsion produced edible films.

\section{Physical and mechanical properties of films:}

Table (3) shows that the thickness value of edible films were $250,220,180$ and 140 um for A, B ,C and D; respectively. The results indicated that treatment $\mathrm{A}$ had the highest thickness value where (D) treatment had the lowest thickness value. Also; it could be observed that the lowest value of tensile strength (52.63 N.M.M ${ }^{2}$, elongation $(17.50 \%)$, (Oxygen 18.28 $\left.\mathrm{M}^{3} . \mathrm{M} / \mathrm{M}^{2} \mathrm{X}^{10-7}\right),(\mathrm{CO} 224.45$ $\left.\mathrm{M}^{3} \cdot \mathrm{M} / \mathrm{M}^{2} \mathrm{X}^{10-8}\right)$, water vapor permeability $0.050[\mathrm{~g} /(\mathrm{s}$. $\left.\mathrm{m}^{2}\right)$ ] and solubility $(11.98 \%)$ Were recorded for treatment (D). where as A, B and C treatments showed higher tensile strength $\left(91.12,83.23\right.$ and 93.33 N.M.M $\left.{ }^{2}\right)$, elongation $(15.25,13.15$ and $35.00 \%$ ) , ( Oxygen , 27.76 , 23.43 and $\left.19.10 \mathrm{M}^{3} . \mathrm{M}^{1} \mathrm{M}^{2} \mathrm{X}^{10-7}\right),(\mathrm{CO} 245.58,37.70$ and 29.26 $\left.\mathrm{M}^{3} . \mathrm{M} / \mathrm{M}^{2} \mathrm{X}^{10-8}\right)$, Water Vapors permeability [0.058,0.045 and $\left.0.056 \mathrm{~g} /\left(\mathrm{s} . \mathrm{m}^{2}\right)\right]$ and solubility $(24.54,18.46$ and 13.28 $\%)$; respectively. High film elongation is always a desirable characteristic if the film is to be used for food applications (Chen, 1995). Similar results were reported by Nelson Caro et al. (2016).

Table 3. Effect of edible films from egg white protein powder on thickness mechanical properties and Permeability of edible films

\begin{tabular}{|c|c|c|c|c|c|c|c|}
\hline Treatments & $\begin{array}{c}\text { Thickness } \\
\text { um }\end{array}$ & $\begin{array}{c}\text { Tensile } \\
\text { strength } \\
(\text { N.M.M.M }) \\
\end{array}$ & $\begin{array}{c}\text { Elongation } \\
(\%)\end{array}$ & 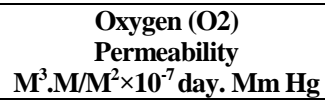 & $\begin{array}{c}\text { CO2 Permeability } \\
\mathrm{M}^{3} \cdot \mathrm{M} / \mathrm{M}^{2} \times 10^{-8} \\
\text { Day. } \mathrm{Mm} \mathrm{Hg} \\
\end{array}$ & $\begin{array}{c}\text { Water vapors } \\
\text { Permeability } \\
\left.\mathrm{G} / \mathrm{m}^{2} .24 \mathrm{hr}\right]\end{array}$ & $\begin{array}{c}\text { "\% } \\
\text { Solubility" }\end{array}$ \\
\hline$\overline{\mathrm{A}}$ & 250 & 91.12 & 15.25 & 27.76 & 45.58 & 0.058 & 24.54 \\
\hline B & 220 & 83.29 & 13.15 & 23.43 & 37.70 & 0.045 & 18.46 \\
\hline $\mathrm{C}$ & 180 & 93.33 & 35.00 & 19.10 & 29.26 & 0.056 & 13.28 \\
\hline $\mathrm{D}$ & 140 & 52.63 & 17.50 & 18.28 & 24.45 & 0.050 & 11.98 \\
\hline
\end{tabular}

A = Edible films+ glycerin $\quad \mathbf{B}=$ Edible films+Sorbitol $\quad$ C=Edible films +rosemary essential oil

D =Edible films +Tripolyphosphate (TPP). 


\section{Microstructure of scanning electron microscopy (SEM)} of films technique:

The microscopic images of four prepared of edible films from egg white protein powder are presented in Figure (2), (A,B,C,and D).The edible films give films characterized with smooth surface and right bottom average size from 20 to $50 \mathrm{um}$. Crystalline granules, polygonal crystal spherical morphology Also, addition of rosemary essential oil gave the thickness of producing films increase the degree of creamy color. The best edible films treatment image characterization was $\mathrm{c}$ average droplet size range (10um) polygonal crystals morphology followed by $\mathrm{D}$ average droplet size range (10um) spherical followed by B average droplet size range (20um) polygonal and ellipsoidal and $\mathrm{A}$ image characterization average droplet size range
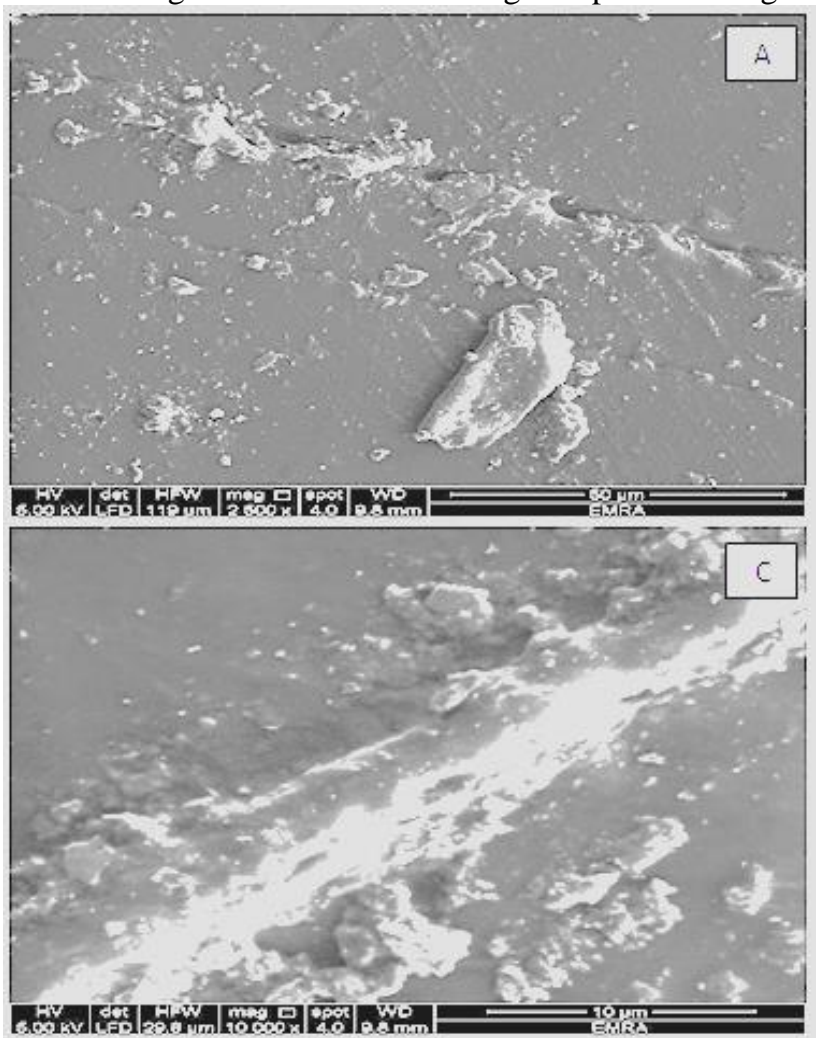

Fig. 2. (A,B,C, and D): SEM micrograph of producing Films

Application of choosing proper edible films to prolong the shelf life of chicken patties

Effect of edible films on microbiology count of chicken patties:-

\section{1- Total bacterial count:}

Total bacterial count of chicken patties coated with edible films was determined along the cold storage period (30 days) at refrigerator $\left(4 \pm 1^{\circ} \mathrm{C}\right)$. Table (4) shows that total bacterial counts of chicken patties gradually increased with the increasing storage period for all treatment control (CL) were , film with glycerin (A), film with sorbitol (B), film with rosemary essential oil (C) and film with tripolyphosphate (D) . It was observed that treatment (C) was the best treatment in terms of reduction the microbial load followed by treatment ( D) followed by treatment( B) until 30 days of storage while the (CL) treatment indicates higher counts than (A) after 20 days of storage.On the other hand the counts reached to $(16.45)$ and $(17.0) \times 10^{2}$ (50um) polygonal and spherical morphology.Scanning electron microscopy of cross-sections of alginate films incorporated with oregano essential oil.The final microstructure of the films results from the internal gelation process of the alginate and the interactions between the components as well as the destabilising phenomena that place during the drying step (Atarés et al., 2010a). SEM analysis showed that the N-Egg protein (EWP) has a porous network structure, loose and irregular. The microscopic structures of Sodium Tripolyphosphate (STP) - EWP -F and STP - EWP-S were very compact, the surfaces of them appeared Very smooth, only at higher magnification we could observe its microstructure characteristics according Liu Lili et al (2015).

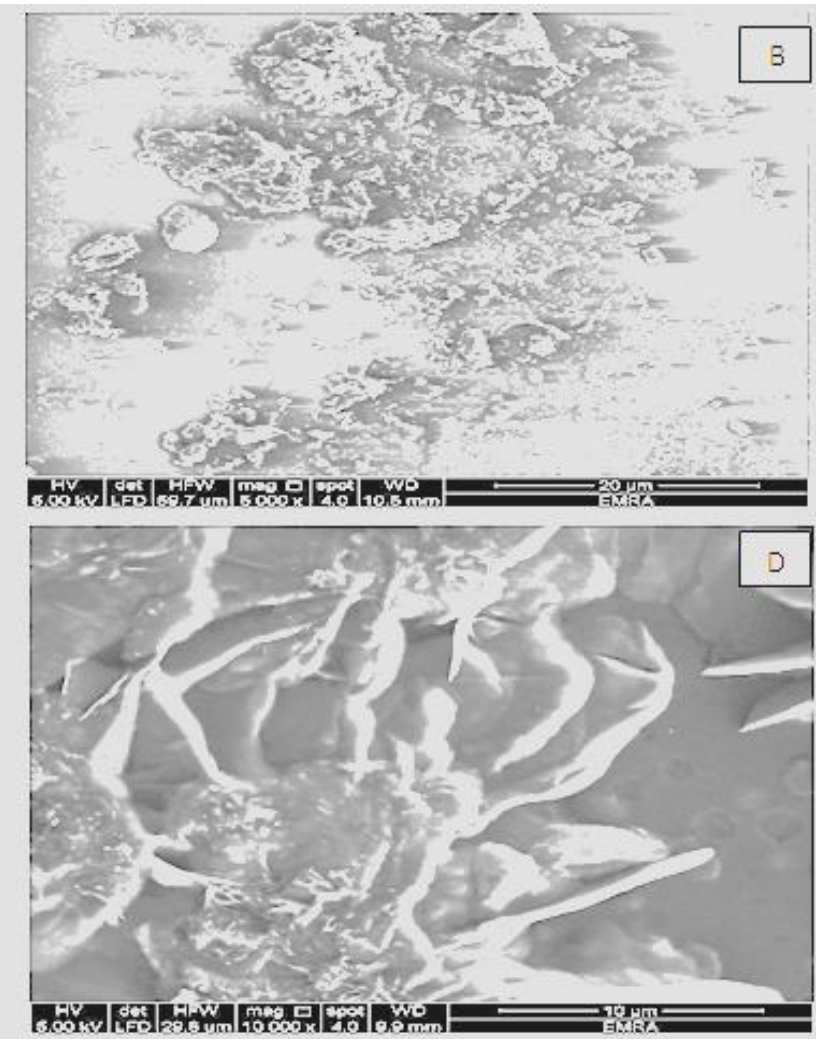

A = Edible films+ glycerin

cfu/g after 30 days of storage in both (C) and (D) treatments as compared with initial counts of 1.20 and 1.28 $\times 10^{2}(\mathrm{cfu} / \mathrm{g})$. Total count of treatment (B) reached at $(18.87) \times 10^{2} \mathrm{cfu} / \mathrm{g}$ after 30 days. Control samples (CL) total bacterial count reached to $(18.75) \times 10^{2}(\mathrm{CFU} / \mathrm{g})$ after 15 days of storage since it become spoiled.

\section{2- Psychrophilic bacteria:}

The results in the table (4) indicate that the counts of psychrophilic bacteria of chicken patties treatments gradually increased with the storage period (30 days) at cold temperature $\left(4 \pm 1^{\circ} \mathrm{C}\right)$ The results indicate that treatment $(\mathrm{C})$ the best in terms of reduction of microbial load followed by treatment (D) followed by treatment (B) until 30 days of storage while the (CL) treatment indicates higher counts than (A) after 20 days of storage. On the other hand the counts reached to $(8.78)$ and $(9.56) \times 102$ $\mathrm{cfu} / \mathrm{g}$ after 30 days of storage in both (C) and (D), as compared with initial counts of 0.35 and $0.38 \times 10^{2}$ 


\section{J. Food and Dairy Sci., Mansoura Univ., Vol. 9 (11), November, 2018}

(CFU/g). Treatment (B) psychrophilic bacteria reached at $(9.74) \times 10^{2} \mathrm{cfu} / \mathrm{g}$ after 30 days. Control treatment $(\mathrm{CL})$ exhibited psychrophilic bacteria of $(9.23) \times 10^{2} \mathrm{cfu} / \mathrm{g}$ after 15 days of storage since it becomes spoiled, as compared with initial counts of $(1.12) \times 10^{2} \mathrm{cfu} / \mathrm{g}$.

\section{3- Molds and yeasts count:}

The changes in molds and yeast count of chicken patties coated with edible films were recorded in the table (4). The results explained that molds and yeast counts gradually increased with the storage period (30 days) at cold temperature $\left(4 \pm 1^{\circ} \mathrm{C}\right)$. Treatment $(\mathrm{C})$ was the best in terms of reduction of molds and yeast load followed by treatment (D) followed by treatment (B) until 30 days of storage while the $(\mathrm{CL})$ edible coating treatment indicates spoiled higher counts than (A) after 20 days of storage. On the other hand the molds and yeast counts reached at $(10.12)$ and $(10.33) \times 10^{2} \mathrm{cfu} / \mathrm{g}$ after 30 days of storage in both (C) and (D) treatments, as compared with initial counts of 1.45 and $1.89 \times 10^{2} \mathrm{cfu} / \mathrm{g}$. As observed that treatment $(\mathrm{B})$ reached at $(11.50) \times 10^{2} \mathrm{cfu} / \mathrm{g}$ after 30 days . Control treatment (CL) molds and yeast count reached at $(11.56) \times 10^{2} \mathrm{cfu} / \mathrm{g}$ after 15 days of storage since it becomes spoiled, as compared with initial counts of $(2.22) \times 10^{2} \mathrm{cfu} / \mathrm{g}$. it could be concluded that the microbial counts of chicken patties coated with edible films were lower than control.

Table 4. microbial examination of chicken patties coated with prepared edible films during cold storage at $\left(4 \pm 1^{\circ} \mathrm{C}\right)$

\begin{tabular}{|c|c|c|c|c|c|}
\hline $\begin{array}{l}\text { Treatments } \\
\text { Storage period days }\end{array}$ & CL & $\mathbf{A}$ & B & $\mathbf{C}$ & D \\
\hline \multicolumn{6}{|l|}{ Total Count $\left(\mathrm{CFUx} 10^{2} / \mathrm{g}\right)$} \\
\hline 0 & 2.45 & 1.60 & 1.45 & 1.20 & 1.28 \\
\hline 5 & 5.90 & 4.10 & 3.85 & 2.45 & 3.67 \\
\hline 10 & 10.25 & 12.60 & 5.56 & 4.20 & 4.89 \\
\hline 15 & 18.75 & 17.45 & 9.10 & 6.45 & 7.76 \\
\hline 20 & reject & 18.30 & 11.98 & 9.98 & 9.12 \\
\hline 25 & reject & reject & 14.32 & 13.00 & 13.45 \\
\hline 30 & reject & reject & 18.87 & 16.45 & 17.00 \\
\hline L.S.D. & & & 2.693 & & \\
\hline \multicolumn{6}{|l|}{ 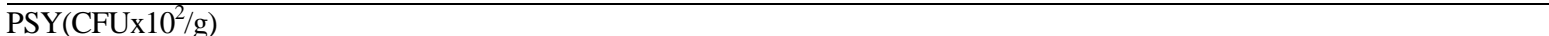 } \\
\hline 0 & 1.12 & 0.45 & 0.40 & 0.35 & 0.38 \\
\hline 5 & 3.95 & 2.20 & 2.11 & 1.95 & 2.12 \\
\hline 10 & 6.12 & 4.23 & 3.70 & 2.67 & 3.43 \\
\hline 15 & 9.23 & 7.45 & 5.78 & 4.21 & 5.00 \\
\hline 20 & reject & 8.45 & 7.45 & 6.45 & 7.20 \\
\hline 25 & reject & reject & 8.20 & 7.36 & 8.23 \\
\hline 30 & reject & reject & 9.74 & 8.78 & 9.56 \\
\hline L.S.D. & & & 1.493 & & \\
\hline \multicolumn{6}{|l|}{ Molds \&Yeast(CFUx10²/g) } \\
\hline 0 & 2.22 & 2.00 & 1.85 & 1.45 & 1.89 \\
\hline 5 & 4.60 & 3.98 & 3.21 & 2.56 & 3.45 \\
\hline 10 & 7.34 & 7.30 & 6.34 & 4.60 & 5.67 \\
\hline 15 & 11.56 & 10.32 & 8.23 & 7.00 & 8.56 \\
\hline 20 & reject & 11.45 & 9.56 & 8.65 & 9.11 \\
\hline 25 & reject & reject & 10.45 & 9.22 & 10.20 \\
\hline 30 & reject & reject & 11.50 & 10.12 & 10.33 \\
\hline L.S.D. & & & 2.452 & & \\
\hline
\end{tabular}

\section{$\mathrm{A}=$ Edible films+ glycerin $\mathrm{B}=$ Edible films+Sorbitol $\mathrm{C}=$ Edible films +rosemary essential oil $\mathrm{D}=$ =Edible films +Tripolyphosphate (TPP) $\mathrm{CL}=\mathrm{Control}$}

\section{Pathogenic bacteria of chicken patties}

The results indicated that pathogenic microorganisms (salmonella spp and coliform group) were not detected, which may be due to the good sanitation practices in production of chicken breast meat and also may be due to that edible coating solutions have been heated just prior to application, which could reduce the load of spoilage and pathogenic microorganisms and partially inactivate deteriorative proteolytic enzymes at the surface of coated meat, poultry as reported by Kuk-Hwan Seol et al. , (2009) , Aristippos Gennadios (1997) and Amin et al., (2015) .

Chemical properties of coated chicken patties:-

Total Volatile Bases Nitrogen (TVB-N), thiobarbituric acid (TBA) and moisture content

Shows statistical analysis that there were significant differences between the different coating during the different storage period as shown in Table (5) which indicates that the level of TVB-N of all chicken patties treatments was increased as cold storage period increased (30 days at $4 \pm 1^{\circ} \mathrm{C}$ ). The results showed that treatments (C) and (D) had the lowest increment rate in TVB-N since they reach the egyptian standards limit (20 mg/100g) (EOS, 2005) after 30 days of cold storage whereas treatments (B) and (A) reach the egyptian standards limit after 20 days of cold storage (20.02 and $24.64 \mathrm{mg} / 100 \mathrm{~g}$; respectively) as control treatment (CL) reach this limit after 15 day of cold storage (24.66 $\mathrm{mg} / 100 \mathrm{~g}$ ) which indicate the effect of coating treatments on retarding protein degradation of chicken patties.

The same effect was observed with the lipid oxidation since, TBA value of control (CL) treatment reach the egyption standarss limit $(0.9 \mathrm{mg}$ malonaldehyde $/ \mathrm{kg})$ (EOS , 2005) after day15 of cold storage (0.973), while the edible coated chicken patties were had lower TBA values since treatments $\mathrm{C}$ and $\mathrm{D}$ reach the spoilage limit after 30 days of cold storage ( 0.934 and $0.935 \mathrm{mg} / \mathrm{kg}$; respectively), whereas $\mathrm{B}$ and $\mathrm{A}$ treatments were near the spoilage limit after 25 days of cold storage $(0.851$ and $0.885 \mathrm{mg} / \mathrm{kg}$; respectively) which indicate that edible coating protect the lipid of chicken patties agnaist oxidation as compared to control treatment which reach the spoilage limit after 15 
days of cold storage $(0.973 \mathrm{mg} / \mathrm{kg})$.The results are in accordance with those of El-sayed (2013) .

The results indicate that edible coatings had good moisture barrier properties which could reduce moisture loss of chicken patties which gradually increased as cold storage period increased. The moistur loss at the $15^{\text {th }}$ day of cold storage was taken as indicator to compare the effect of moisture loss (since control treatment was spoiled after that), the results indicate that the percentage of moisture loss in all treatments, was different,scince treatment A had the lowest moisture content percent $(6.77 \%)$ after 20 days of cold storage while the control (CL) treatment had the highest moisture content percent $(16.58 \%)$ after 15 days of cold storage where the moisture content of treatments B , C and D were $9.68,10.85$ and $11.28 \%$ respectively after 30 days of cold storage. These results are in agreement with Aristippos Gennadios (1997) who reported that edible coatings could prevent moisture loss during food storage.

\begin{tabular}{|c|c|c|c|c|c|}
\hline Treatments / Storage period days & CL & $\mathbf{A}$ & B & $\mathrm{C}$ & D \\
\hline \multicolumn{6}{|l|}{ TVB-N(mg\100g) } \\
\hline 0 & 7.45 & 7.43 & 7.42 & 7.40 & 7.40 \\
\hline 5 & 13.96 & 9.78 & 9.53 & 8.22 & 8.0 \\
\hline 10 & 18.11 & 13.93 & 13.85 & 11.74 & 10.33 \\
\hline 15 & 24.66 & 17.48 & 17.1 & 14.69 & 13.95 \\
\hline 20 & - & 24.64 & 20.02 & 16.42 & 14.34 \\
\hline 25 & - & - & 23.54 & 18.08 & 17.18 \\
\hline 30 & - & - & 23.90 & 20.4 & 20.05 \\
\hline L.S.D. & & & 1.194 & & \\
\hline \multicolumn{6}{|l|}{ TBA(mg malonaldehyde $\backslash \mathrm{Kg})$} \\
\hline o & 0.130 & 0.127 & 0.124 & 0.122 & 0.118 \\
\hline 5 & 0.456 & 0.279 & 0.258 & 0.258 & 0.248 \\
\hline 10 & 0.762 & 0.441 & 0.382 & 0.377 & 0.369 \\
\hline 15 & 0.973 & 0.612 & 0.521 & 0.515 & 0.499 \\
\hline 20 & - & 0.766 & 0.699 & 0.690 & 0.683 \\
\hline 25 & - & 0.885 & 0.851 & 0.769 & 0.768 \\
\hline 30 & _ & 1.184 & 1.115 & 0.934 & 0.935 \\
\hline L.S.D. & & & 0.673 & & \\
\hline \multicolumn{6}{|l|}{ Moisture content (\%) } \\
\hline 0 & 74.10 & 74.70 & 74.68 & 74.46 & 74.44 \\
\hline 5 & 70.09 & 73.46 & 73.31 & 72.30 & 72.02 \\
\hline 10 & 65.15 & 72.27 & 71.28 & 71.00 & 70.14 \\
\hline 15 & 61.81 & 71.87 & 70.67 & 69.26 & 68.1 \\
\hline 20 & - & 69.64 & 68.56 & 67.20 & 67.07 \\
\hline 25 & - & - & 68.19 & 67.06 & 66.95 \\
\hline 30 & - & - & 67.45 & 66.38 & 66.04 \\
\hline L.S.D. & & & 2.342 & & \\
\hline
\end{tabular}

Control = without coating $\quad A=$ Edible films+glycerol $\quad$ B =Edible films+Sorbitol $\quad$ C=Edible films +rosemary essential oil $\quad$ D =Edible films +Tripolyphosphate (TPP) $\mathrm{CL}=$ Control

Physico-chemical characteristics of coated chicken patties:-

The data in Figure (3) show changes in physic chemical properties of chicken patties treated with an edible coating during cold storage. From the results, it could be observed that WHC of edible coated chicken patties decreased as cold storage decreased. The highest WHC recorded for treatment $\mathrm{B}$ while the lowest WHC recorded for control (uncoated)treatment. Also, control treatment had the lowest plasticity while coated chicken patties had higher plasticity, which nonsignificatly different. As observed that $\mathrm{pH}$ values slightly increased as cold storage period increased. Control treatment recorded the highest $\mathrm{pH}$ value as compared to coated treatments, which had nearly similar $\mathrm{pH}$ values. El -Safy (2004) found that the $\mathrm{pH}$ value of fresh chicken breast ranged between 5.6 to 6.0. The results also show that the weight loss, increased cold storage period increased. The highest weight loss recorded for control treat while treatment $\mathrm{B}$ exhibited the lowest weight loss values along cold storage period. These results are in agreement with those of Yildirim et al. (2005); Osheba et al., (2008) El-Sayed (2013) who reported that document in the WHC and plasticity may be due to many possible reasons such as denaturation and aggregation of protein (possible formation of disulphide bonds) and association of lipid hydrolysis and oxidation end products with protein. Rendering them insoluble and decreasing tenderness and plasticity. In general, the results showed that there were significant differences between all different treatments during different storage periods. It is clear that the best treatment is C followed by D followed by B .

Sensory properties of coated patties during cold storage:

The mean scores of sensory properties (appearance, taste, texture and overall palatability) of chicken patties are shown in fig (4). The results that chicken patties were high palatability for panelists and were generally having high acceptance at the first day and was fairly equal. Control (CL) treatment rejected after the 15 days of storage while coated treatment continued with the (A) edible coating till day 20, whereas treatment (C) showed the highest sensory acceptance, followed by treatment (D), followed by treatment (B) until 30 days of cold storage . On the other hand the results of the statistical analysis were shown that treatments $\mathrm{C}$ and $\mathrm{D}$ had the best appearance followed by treatment $(\mathrm{B})$. Regarding taste and texture $\mathrm{t}$ treatment $\mathrm{C}$ showed the highest values followed by B and D treatments along storage period. In respect to overall all treatments were highly accepted at zero time storage, but after 30 days treatment $\mathrm{C}$ acceptable treatments followed by $\mathrm{D}$ then A Treaments. The results are in agreement with those obtained by El-Sayed (2013). It has become clear through the results that the difference in films resulted in significant differences between the treatments during the different storage periods. 

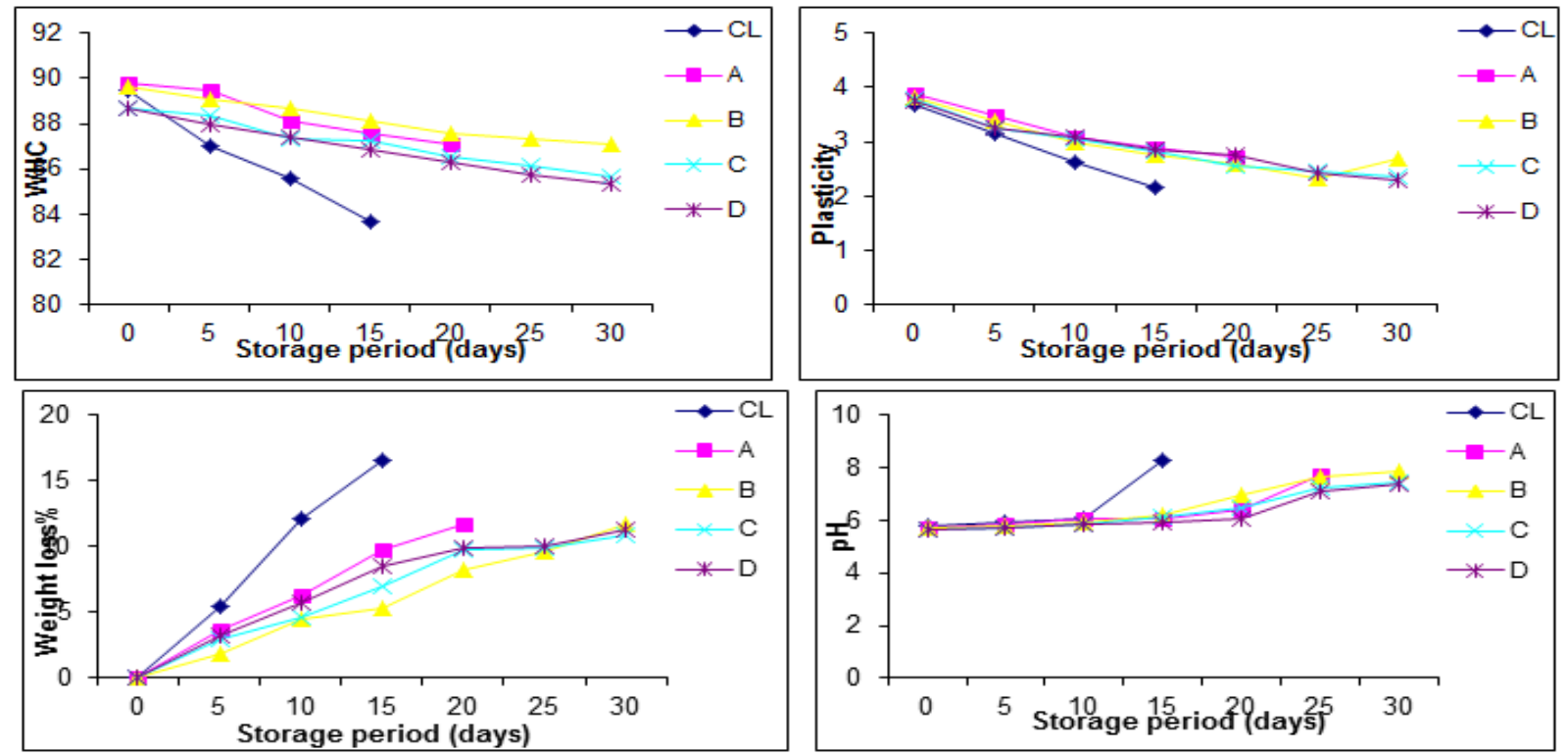

Fig .3. Some Physico-chemical characteristics of coated chicken patties during cold storage at $\left(4 \pm 1^{\circ} \mathrm{C}\right)$. WHC [LSD $0.05=0.925]$, Plasticity [LSD 0.05 = 0.756], Weight loss \% [LSD 0.05 $=0.252], \mathrm{pH}[\mathrm{LSD} 0.05=0.185]$.
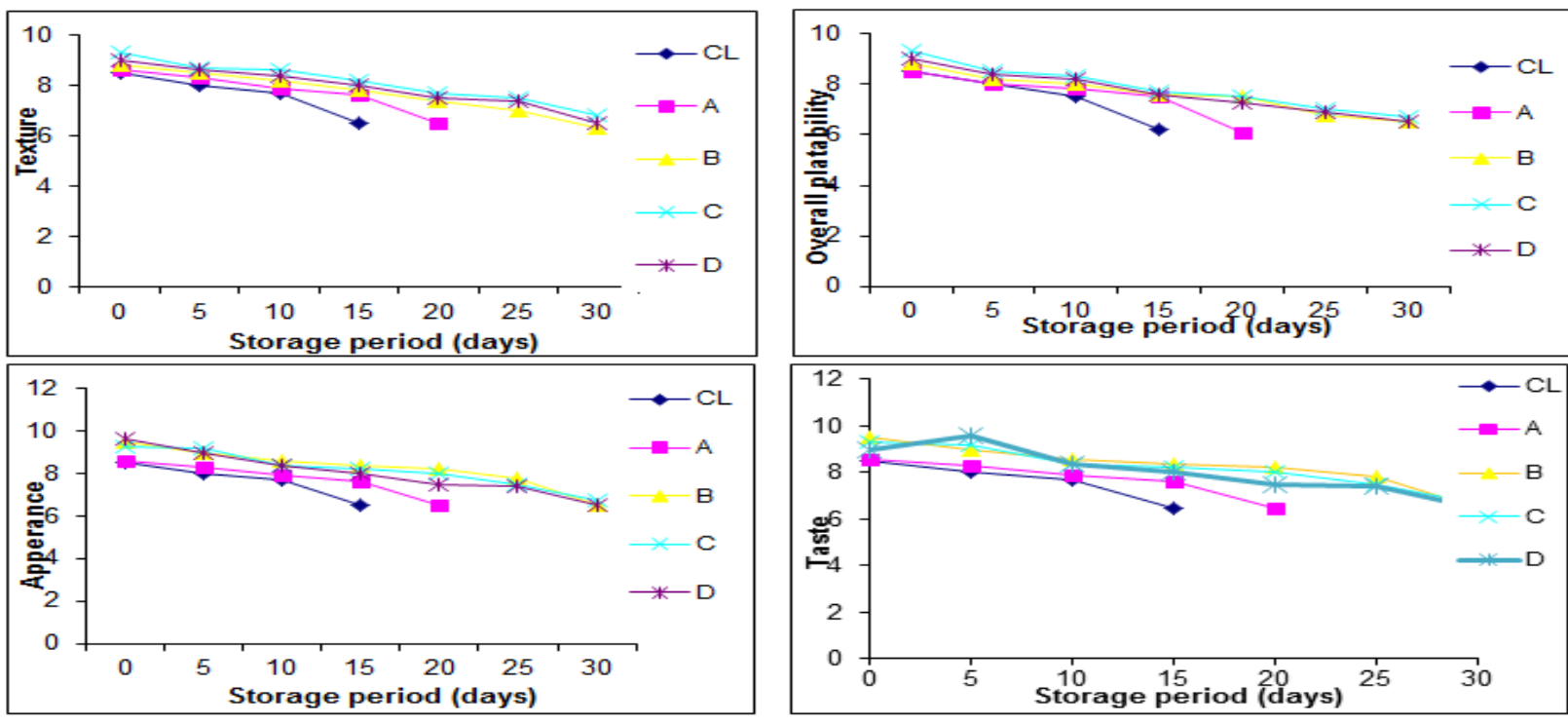

Fig 4. Sensory evaluation of coated chicken patties during cold storage $\left(4 \pm 1^{\circ} \mathrm{C}\right)$. Appearance [LSD0.05 $=1.4987$, Taste [LSD0.05 $=1.976]$, Texture $[$ LSD0.05 $=1.867]$, Overall palatability [LSD0.05 $=1.842$.

\section{CONCLUSION}

This investigation was carried out as trial to use egg white protein in the preparation of edible coating for chicken patties during storage at $4 \pm 1^{\circ} \mathrm{C}$ for 30 days . The prepared coating was evaluated through determination some physical ,chemical, microbial properties. Also, the stored coated chicken patties were evaluated.The results indicated that a film with rosemary essential oil (C) was the best one in terms of reduction microbial load followed by film with (TPP) (D) followed by film with sorbitol (B) until 30 days of storage as compared to control. It is clear that the edible coating containing aromatic essential oils and (TPP) has kept the quality charchtristics of chicken patties up to 30 days of storage.

\section{REFERENCES}

Abeyrathne., E. D. N. S., Lee, H. Y., \& Ahn, D. U. (2013). Egg white proteins and their potential use in food processing or as nutraceutical and pharmaceutical agents -- a review. Poultry Science, 92(12), 3292- 3299.
Amin N. Olaimat., Richard A. Holley (2015) Control of Salmonella on fresh chicken breasts by k- carrageenan / chitosan -based coatings containing allyl isothiocyanate or deodorized Oriental mustard extract plus EDTA . Food Microbiology $48,83-88$

Andrzej Tyburcy and Daniel Kozyra (2010) Effects of composite surface coating and pre-drying on the properties of kabanosy dry sausage. Meat Science 86 405-410

AOAC., 2000. Official Methods of Analysis. 17th Ed. OF the Association of Official Analytical Chemists. Gaithersburg, Maryland, USA.

Aristippos Gennadios, Milford A. Hanna* and Lyndon B. Kurth (1997) Application of Edible Coatings on Meats, Poultry and Seafoods: A Review . Lebensm.Wiss. U .Technol., $30,337-350$

Atarés, L., Bonilla, J., Chiralt, A., (2010)a. Characterization of sodium caseinate-based edible films incorporated with cinnamon or ginger essential oils. Journal of Food Engineering 100, 678-687.

Bourtoom, T. (2008). Edible films and coatings: characteristics and properties. International Food Research Journal, 15(3), 237-248. 
Burt, S. (2004). Essential oils, their antibacterial properties and potential applications in foods-a review. International Journal of Food Microbiology, 94 (3), 223-253.

Catherine Nettles Cutter (2006) Opportunities for bio-based packaging technologies to improve the quality and safety of fresh and further processed muscle foods. Meat Science 74 ,131-142

Coma, V., Martıal-Gros, A., Garreau, S., Copınet, A., Salın, F., \& Deschamps, A. (2002). Edible antimicrobial films based on chitosan matrix. Journal of Food Science, 67 (3), 11621169.

El-sayed , S.M (2013). Influence of Using Lupine Flour as Binder on Quality Characteristics of Beef Burger Patties . Journal of Applied Sciences Research, 9(6): 3809-3819.

El - Safy, Samia F.Y. (2004) : Chemical and organoleptic study on some frozen foods during handling and processing. PH. D. Thesis, Fac. Agric. Al-Azhar Univ.

EOS, Egyptian organization of standardization (2005). Egyption standards of chicken and turkey meat products, 2910/2005.

FAO (1979) Manuals of Food Quality Control, Microbiological Analysis of the United Nations, FAO, Rome, Italy.

FDA (2000) Bacteriological Analytical Manual. In: Compendium of microbiological methods for the analysis of food and agricultural methods. Association of Official Analytical Chemists, FDA, Arlington, Virginia, USA.

Jiang Jiang and Youling L Xiong(2016) Natural antioxidants as food and feed additives to promote health . Meat Science $120,107-117$ benefits and quality of meat products: A review

Ko, K. Y., \& Ahn, D. U. (2008). An economical and simple purification procedure for the large scale production of ovotransferrin from egg white. Poultry Science, 87(7), 1441-1450.

Kovacs-Nolan, J. K. N., Phillips, M., \& Mine, Y. (2005). Advances in the value of eggs and egg components for human health. Journal of Agricultural and Food Chemistry, 53(22), 8421-8431.

Kuk-Hwan Seol a, Dong-Gyun Lim a, Aera Jang b, Cheorun Jo c Mooha Lee a .(2009)the antimicrobial effect of jcarrageenan-based edible film containing ovotransferrin in fresh chicken breast stored at $5{ }^{\circ} \mathrm{C}$. Meat Science 83,479483.

Krochta , J. M., \& De Mulder, Johnston C. (1997). Edible and biodegradable polymer films:Challenges and opportunities. Food Technology, 51(2), 60-73.

ISO (2001) Microbiology of Food and Animal Feeding Stuffs Horizontal Method for the Enumeration of Bglucuronidase -positive Escherichia coli. Part 2: Colonycount technique at $44^{\circ} \mathrm{C}$ using 5- bromo -4- chloro-3indoyl -beta-D- glucuronide. ISO 16649-2.

Liu Lili*, Wang Huan, Ren Guangyue, Duan Xu, Li Dan, Yin Guangjun (2015) Effects of freeze-drying and spray drying processes on functional properties of phosphorylation of egg white protein. Int J Agric \& Biol Eng,Vol. 8 No.4, 116-123

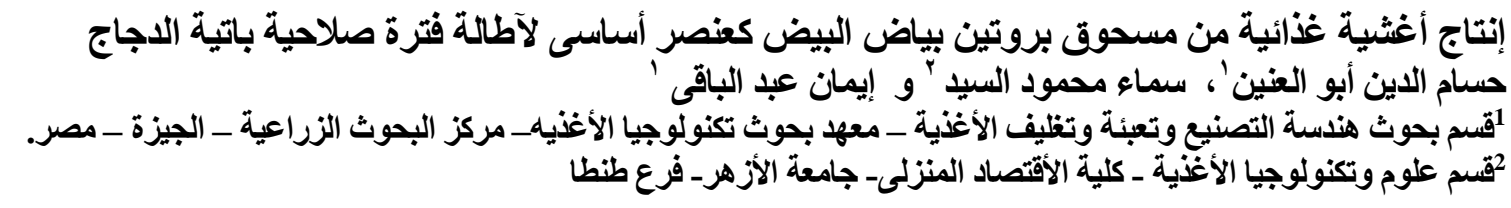

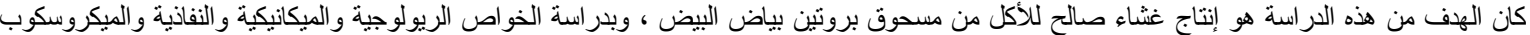

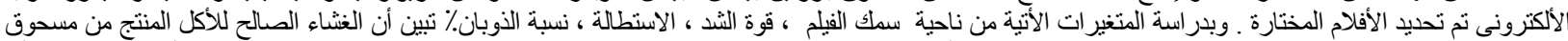

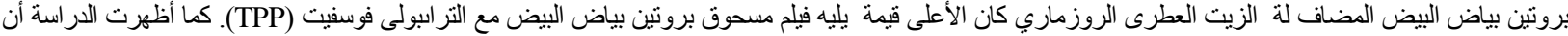

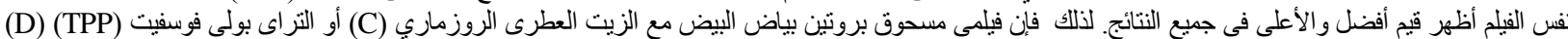

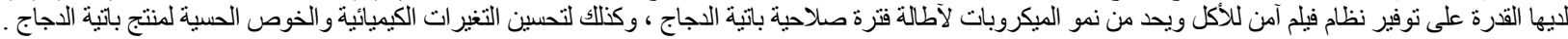

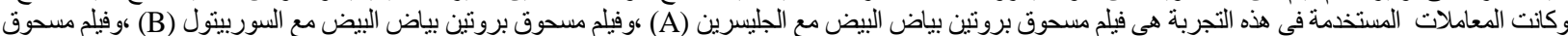

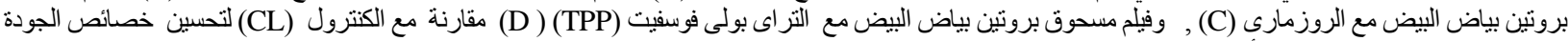

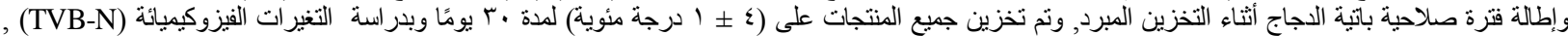

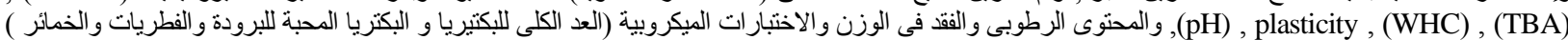

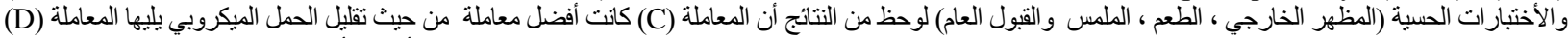

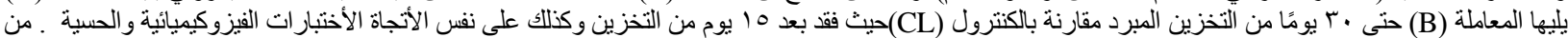

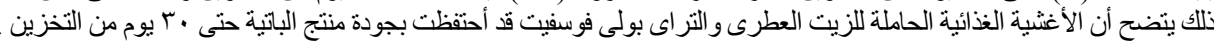

